\title{
PENGARUH DEPOSIT STRUCTURE DAN OWNERSHIP CONCENTRATION TERHADAP PENGUNGKAPAN ISLAMIC CORPORATE GOVERNANCE PADA BANK SYARIAH DI INDONESIA DAN MALAYSIA
}

\author{
Hasna Katsurayya, Tettet Fitrijanti, Fury Khristianty Fiitriyah \\ Universitas Padjajaran (UNPAD) Bandung \\ hasnakatsurayya@gmail.com, tettet.fitrijanti@fe.unpad.ac.id,furykf@gmail.com \\ https://doi.org/10.46367/jas.v4i1.194 \\ Received: Jan 10, 2020 Revised: Apr 02, 2020 Accepted: Mei 11, 2020 Published: Jun 25, 2020
}

\begin{abstract}
This research aims to determine the effect of Deposit Structure and Ownership Structure on the disclosure of Islamic Corporate Governance (ICG). Deposit Structure is proxied by the percentage of the Profit Sharing Investment Account (PSIA) to assets, while Ownership Structure used in this research is Blockholder Ownership and Managerial Ownership. The research uses descriptive and verification method with quantitative analysis approach. The results show that simultaneous Profit Sharing Investment Account, Blockholder Ownership, and Managerial Ownership has significant effect on the disclosure of ICG. Partially, Profit Sharing Investment Account indicates significant positive effect on the disclosure of ICG, Blockholder Ownership shows significant positive effect on the disclosure of ICG, while the Managerial Ownership does not affect the disclosure of ICG.
\end{abstract}

Keywords: Islamic Corporate Governance Disclosure, PSIA, Blockholder Ownership, Managerial Ownership.

\begin{abstract}
ABSTRAK
Penelitian ini bertujuan untuk mengetahui pengaruh Deposit Structure dan Ownership Structure terhadap pengungkapan Islamic Corporate Governance (ICG). Deposit Structure diproksikan dengan persentase Profit Sharing Investment Account (PSIA) terhadap aset, adapun Ownership Structure yang digunakan dalam penelitian ini adalah Blockholder Ownership dan Kepemilikan Manajerial. Metode yang digunakan dalam penelitian ini adalah metode deskriptif dan verifikatif dengan pendekatan analisis kuantitatif. Hasil penelitian menunjukkan bahwa secara simultan Profit Sharing Investment Account, Blockholder Ownership dan Kepemilikan Manajerial berpengaruh signifikan terhadap pengungkapan ICG. Secara parsial Profit Sharing Investment Account berpengaruh positif signifikan terhadap pengungkapan ICG, Blockholder Ownership berpengaruh positif signifikan terhadap pengungkapan ICG, sedangkan Kepemilikan Manajerial tidak berpengaruh terhadap pengungkapan ICG.
\end{abstract}

Kata Kunci: Pengungkapan Islamic Corporate Governance, PSIA, Blockholder Ownership, Kepemilikan Manajerial. 


\section{PENDAHULUAN}

Pengungkapan Corporate Governance (CG) yang transparan dan akuntabel merupakan salah satu cara yang dapat dilakukan oleh perbankan syariah untuk menampilkan kualitas tata kelola yang mereka terapkan dalam rangka memperbaiki reputasi bank syariah di mata masyarakat (Albassam et al. 2017). Pengungkapan Islamic Corporate Governance (ICG) berpengaruh positif signifikan terhadap kinerja keuangan bank (Srairi 2015; Yadiat et al. 2017), Hasil penelitian tersebut menunjukkan bahwa penerapan dan pengungkapan praktik CG dalam perspektif Islam sama pentingnya sebagaimana strategi bisnis dalam menciptakan keunggulan kompetitif yang berkelanjutan.

Berbagai penelitian yang membahas tentang pengungkapan Corporate Governance, Darmadi (2013) meneliti pengungkapan CG pada bank syariah di Indonesia menunjukkan nilai rata-rata pengungkapan yang relatif rendah, yaitu $60 \%$. Penelitian Sulaiman (2015) tentang pengungkapan CG pada perbankan syariah di Malaysia pun menunjukkan hasil pengungkapan CG yang masih rendah dengan nilai rata-rata pengungkapan 51,42\%. Abdullah et al. (2013) meneliti 23 bank syariah di Indonesia dan Malaysia menemukan rata-rata tingkat pengungkapan ICG sebesar 52\%. Berdasarkan persentase tersebut menunjukkan tingkat pengungkapan ICG perbankan syariah di negara Indonesia dan Malaysia tergolong masih rendah.

Keunikan karakteristik dari perbankan syariah, dimana para deposan Profit Sharing Investment Account (PSIA) berbagi keuntungan dan kerugian dengan bank syariah, menjadi daya tarik untuk melihat sejauh mana faktor dari struktur kepemilikan akun oleh para depositor di bank syariah atau struktur deposit (deposit structure), dalam mempengaruhi tingkat pengungkapan Islamic Corporate Governance. Penelitian sebelumnya ditunjukkan oleh penelitian Grassa (2018) dimana bank syariah dengan konsentrasi kepemilikan yang tinggi, leverage yang tinggi dan tingkat non-Profit Sharing Investment Account (PSIA) yang tinggi melakukan pengungkapan ICG yang lebih rendah. Adapun bank syariah yang memiliki konsentrasi Profit Sharing Investment Account (PSIA) yang tinggi, ukuran bank, usia bank, bank yang listed, dan indeks transparansi negara melakukan pengungkapan ICG yang lebih tinggi.

Peneliti lainnya melihat stuktur kepemilikan (ownership structure) sebagai faktor yang mempengaruhi tingkat pengungkapan ICG (Khan et al. 2017; Albassam et al. 2017; Elmagrhi 2016; Hikmah dan Rahmayanti, 2011). Penelitian ini menggunakan blockholder ownership dan managerial ownership karena kedua stuktur kepemilikan tersebut adalah struktur kepemilikan yang paling berpengaruh untuk mengurangi agency cost.

Penelitian ini merupakan pengembangan dari penelitian Grassa (2018), yang merupakan penelitian pertama yang meneliti pengaruh deposit structure dan ownership concentration terhadap ICGD, dengan membedakan hal-hal berikut: (1) sampel yang digunakan, yaitu perbankan syariah di Indonesia dan Malaysia. Indonesia dan Malaysia sebagai negara berkembang terletak di wilayah yang sama dengan budaya yang relatif sama secara substansial mempromosikan sistem perbankan Islam. Pada dua negara tersebut, Islam adalah agama mayoritas dengan jumlah populasi Muslim, kedua negara ini menyumbang sekitar 14\% dari populasi Muslim dunia (PewResearch Center 2009 dalam Amran 2017). (2) Indeks 
pengukuran ICG, yaitu menggunakan indeks pada penelitian Yadiat et al. (2017) yang disusun berdasarkan standar CG khusus Lembaga Keuangan Syariah Internasional, yaitu GSIFI (Governance Standard for Islamic Financial Institutions)-AAOIFI (Accounting and Auditing Organization for Islamic Financial Institutions) dan IFSB (Islamic Financial Standard Board), serta berbagai penelitian sebelumnya.

\section{TELAAH LITERATUR}

\section{Agency Theory}

Dalam kerangka teori keagenan, Jensen dan Mecklin dalam Jao dan Pagalung (2011) menjelaskan bahwa hubungan agensi terjadi ketika satu orang atau lebih (prinsipal) mempekerjakan orang lain (agen) untuk memberikan suatu jasa dan kemudian mendelegasikan wewenang pengambilan keputusan. Prinsipal adalah pemegang saham atau investor, sedangkan agen adalah manajemen yang mengelola perusahaan atau manajer. Inti dari hubungan keagenan adalah adanya pemisahan fungsi antara kepemilikan di investor dan pengendalian di pihak manajemen. Adanya pemisahan antara pemilik perusahaan dan pengelolaan oleh manajemen cenderung menimbulkan konflik keagenan di antara prinsipal dan agen. Konflik kepentingan antara prinsipal dan agen terjadi karena kemungkinan agen tidak selalu berbuat sesuai dengan keinginan prinsipal, sehingga menimbulkan biaya keagenan (agency cost). Dengan adanya masalah-masalah konflik kepentingan dan biaya-biaya agensi yang akan timbul maka diperlukan suatu konsep yang lebih jelas mengenai perlindungan terhadap stakeholders. Untuk itu, berkembang suatu konsep yang memperhatikan dan mengatur kepentingan para pihak yang terkait dengan pemilik dan pihak operasional suatu perusahaan yang dikenal dengan konsep corporate governance.

\section{Asimetri Informasi}

Scott (2011) menyatakan bahwa informasi dianggap asimetri jika satu pihak memiliki informasi yang lebih banyak dibandingkan pihak lainnya. Terdapat dua tipe asimetri utama yaitu (1) adverse selection dan (2) moral hazard. Adverse selection is a type of information asymmetry whereby one or more parties to business transaction, or potential transaction, have an information advantage over other parties. Moral hazard is a type of information asymmetry whereby one or more parties to a business transaction, or potential transaction, can observe their actions in fulfillment of the transaction but other parties not.

\section{Islamic Corporate Governance}

Islamic Corporate Governance (ICG) merupakan istilah corporate governance dalam perspektif Islam (Lewis 2005; Hasan 2009; Abu-Tapanjeh 2009; Bhatti dan Ishaq 2009). Pada dasarnya, Islamic Corporate Governance (ICG) memiliki tujuan yang sama dengan corporate governance umumnya, perbedaannya, ICG mengacu pada nilai agama Islam. ICG memadukan antara hukum Islam dengan model stakeholder dalam corporate governance (Bhatti dan Ishaq 2009).

Menurut Lewis (2005), terdapat dua sifat dari ICG. Pertama, seluruh aspek kehidupan, etika dan sosial perusahaan harus mengacu pada hukum Islam. Kedua, 
ICG juga harus mengacu pada etika bisnis dan prinsip-prinsip ekonomi dan keuangan Islam, di antaranya terkait dengan perintah zakat, pelarangan riba, larangan spekulasi dan perintah untuk mengembangkan sistem ekonomi berdasarkan profit and loss sharing.

Berdasarkan pengertian di atas, dapat disimpulkan bahwa Islamic Corporate Governance merupakan corporate governance yang memadukan model stakeholder dengan hukum Islam sebagai landasan dalam menjalankan perusahaan. Perusahaan tidak hanya harus menjaga akuntabilitasnya di mata stakeholder, namun juga menjalankan perusahaan berdasarkan prinsip-prinsip syariah dan menjaga akuntabilitas kepada Allah SWT.

\section{Deposit Structure}

Deposit structure adalah susunan dari unsur-unsur simpanan dalam perbankan syariah, Dalam bank syariah, klasifikasi penghimpunan dana didasarkan atas prinsip yang digunakan, bukan atas nama produk. Berdasarkan fatwa Dewan Syariah Nasional, bank syariah dapat menggunakan prinsip penghimpunan dana berdasarkan dua, yaitu prinsip wadi'ah (titipan/non-Profit Sharing Investment Account) dan prinsip mudharabah (bagi hasil/ Profit Sharing Investment Account). Prinsip wadi'ah dalam perbankan syariah diterapkan dalam penghimpunan dana dalam bentuk giro dan tabungan (Antonio 2001).

\section{Ownership Structure}

Struktur kepemilikan saham menjabarkan pihak-pihak yang memiliki saham suatu perusahaan, hal ini menunjukkan bahwa pihak-pihak tersebut dapat dikatakan sebagai pemegang kekuasaan atas perusahaan, didasarkan pada jumlah saham yang dimiliki oleh masing-masing pihak. Menurut Thomsen et al. (2006), blockholder didefinisikan sebagai pemegang saham yang kepemilikannya paling sedikit $5 \%$.

Adapun, kepemilikan manajerial adalah jumlah saham yang dimiliki oleh pihak manajemen dibandingkan dengan seluruh modal saham (Boediono 2005). Kepemilikan manajerial sangat penting, karena hal ini berkaitan dengan pengendalian operasional perusahaan. Dalam aplikasinya, kepemilikan manajerial akan mempengaruhi penentuan kebijakan serta pengambilan keputusan atas metode akuntansi yang akan digunakan perusahaan. Kepemilikan manajerial juga merupakan salah satu cara untuk mengurangi agency cost (Boediono, 2005).

\section{Hipotesis}

Konsep penggunaan model bagi hasil pada (profit sharing) pada bank syariah ini memikat para investment depositors. Sejumlah $62 \%$ dari rata-rata aset pada bank syariah di India dan 12 negara di Timur Tengah dan Asia Tenggara merupakan bagian dari Profit Sharing Investment Account (Archer et al. 2010).

Dalam perbankan syariah, para investment depositors menjadi bagian dari konflik agensi. Hal ini dikarenakan para investment depositors pada bank syariah berpartisipasi dalam laba rugi seperti halnya pemegang saham, namun mereka tidak memiliki jaminan atau hak suara untuk melindungi kepentingan diri mereka dari kesalahan manajemen, maka membuat mekanisme tata kelola yang baik sangat diperlukan untuk melindungi kepentingan mereka dan untuk menjaga kepercayaan para investment depositors (Darmadi 2013). Untuk memperoleh 
informasi dalam membuat keputusan, seperti halnya pemegang saham minoritas, investment depositors mengandalkan informasi yang diungkapkan dalam laporan keuangan. Secara teori, mudharabah, salah satu akad dalam prinsip bagi hasil, tidak hanya meningkatnya adverse selection, moral hazard dan monitoring cost (Chong dan Ming-Hua 2009), tapi juga memperparah masalah keagenan dengan meningkatkan peluang untuk pengambilalihan manajerial atas aset perusahaan (Safieddine 2009).

Penelitian Yadiat et al. (2017) menunjukkan, pengungkapan ICG pada perbankan syariah di negara QISMUT berpengaruh positif signifikan terhadap disiplin pasar serta kinerja keuangan bank yang dihitung menggunakan rasio ROA dan ROE. Sejalan dengan penelitian sebelumnya yang dilakukan oleh Srairi (2015) pada perbankan syariah di negara GCC yang juga menunjukkan pengungkapan ICG berpengaruh signifikan terhadap kinerja bank syariah. Hasil penelitian tersebut menunjukkan bahwa penerapan dan pengungkapan praktik CG dalam perspektif Islam sama pentingnya sebagaimana strategi bisnis dalam menciptakan keunggulan kompetitif yang berkelanjutan.

Grassa (2018) meneliti pengaruh deposit structure yang dikelompokkan menjadi Profit Sharing Investment Account (PSIA) dan non-PSIA terhadap pengungkapan Islamic Corporate Governance. Hasil penelitian menunjukkan indeks pengungkapan ICG lebih rendah pada bank syariah dengan konsentrasi kepemilikan non-PSIA yang tinggi, sedangkan indeks pengungkapan ICG lebih besar pada bank syariah dengan konsentrasi kepemilikan PSIA yang tinggi. Perbankan syariah dengan equity-based capital structure yang didominasi oleh kepemilikan PSIA memiliki risiko yang besar dengan adanya penarikan dana oleh para investment depositors atau pemilik akun PSIA. Sehingga bank syariah meningkatkan pengungkapannya untuk mempertahankan para pemilik akun PSIA. Berdasarkan uraian tersebut, maka diajukan hipotesis pertama sebagai berikut: Deposit Structure berpengaruh positif terhadap tingkat pengungkapan Islamic Corporate Governance.

Kepemilikan saham dengan konsentrasi tinggi akan menyebabkan informasi yang diungkapkan semakin sedikit. Sebaliknya, apabila kepemilikan saham semakin tersebar, semakin banyak informasi yang diungkapkan dalam laporan tahunan. Hal ini terjadi karena adanya dorongan publik dalam memperoleh sebanyak mungkin informasi terkait perusahaan tempat ia berinvestasi, sebagai salah satu bentuk pengawasan publik terhadap manajemen (Nuryaman 2009). Penelitian terdahulu menunjukkan tingkat pengungkapan Corporate Governance memiliki hubungan negatif dengan kepemilikan blockholder (Albassam 2017; Khan et al. 2017; Elmagrhi 2016; Nelwan 2017; Ntim et al. 2012). Sehingga, semakin banyak jumlah kepemilikan blockholder akan menyebabkan pengungkapan Islamic Corporate Governance berkurang. Berdasarkan uraian di atas maka diajukan hipotesis kedua sebagai berikut: Blockholder Ownership berpengaruh negatif terhadap tingkat pengungkapan Islamic Corporate Governance.

Menurut Boediono (2005) kepemilikan manajerial sangat penting, karena hal ini berkaitan dengan pengendalian operasional perusahaan. Dalam aplikasinya, kepemilikan manajerial akan mempengaruhi penentuan kebijakan serta pengambilan keputusan atas metode akuntansi yang akan digunakan perusahaan. 
Dikaitkan dengan pengungkapan, semakin banyak kepemilikan manajerial akan menyebabkan pengungkapan yang lebih sedikit.

Penelitian Elmagrhi (2016) dan Nelwan (2017) menunjukkan kepemilikan manajerial berpengaruh negatif terhadap pengungkapan Islamic Corporate Governance, artinya semakin banyak kepemilikan manajerial maka semakin rendah tingkat pengungkapan. Hal ini dikarenakan pihak manajemen sudah memiliki akses informasi yang besar tanpa harus melalui laporan tahunan perusahaan terpublikasi atau bahkan pihak manajemen dengan sengaja menahan informasi agar terhindar dari terjadinya pemanfaatan informasi oleh pihak-pihak yang merupakan pesaing perusahaan (Nuryaman 2009, 105). Berdasarkan uraian tersebut, maka diajukan hipotesis ketiga sebagai berikut: Kepemilikan Manajerial berpengaruh negatif terhadap tingkat pengungkapan Islamic Corporate Governance.

\section{METODE PENELITIAN}

Periode penelitian ini adalah tahun 2013-2017. Periode dipilih untuk melihat kondisi yang relatif terbaru, serta diawali pada tahun 2013, dimana pada tahun tersebut terjadi penurunan pertumbuhan ekonomi pada negara Indonesia dan Malaysia. Populasi pada penelitian ini ialah perbankan syariah pada negara Indonesia dan Malaysia Jumlah populasi dalam penelitian ini sebanyak 29 perusahaan.

Tabel 1 Perbankan Syariah di Indonesia dan Malaysia

\begin{tabular}{ccl}
\hline Negara & No & \multicolumn{1}{c}{ Nama Bank Syariah } \\
\hline Indonesia & 1 & PT. Bank Muamalat Indonesia \\
& 2 & PT. Bank Victoria Syariah \\
3 & PT. Bank BRI Syariah \\
& 4 & PT. Bank Jabar Banten Syariah \\
& 5 & PT. Bank BNI Syariah \\
& 6 & PT. Bank Syariah Mandiri \\
& 7 & PT. Bank Mega Syariah \\
& 8 & PT. Bank Panin Syariah \\
& 9 & PT. Bank Syariah Bukopin \\
& 10 & PT. BCA Syariah \\
& 11 & PT. Maybank Syariah Indonesia \\
& 12 & PT. Bank Tabungan Pensiunan Nasional Syariah \\
& 13 & PT. Bank Aceh \\
\hline Malaysia & 1 & Affin Islamic Bank Berhad \\
& 2 & Al Rajhi Banking \& Investment Corporation (Malaysia) \\
& 3 & Berhad \\
& 4 & Alliance Islamic Bank Berhad \\
5 & Asian Finance Bank Berhad \\
6 & Bank Islam Malaysia Berhad
\end{tabular}




\begin{tabular}{cll}
7 & Bank Muamalat Malaysia Berhad \\
8 & CIMB Islamic Bank Berhad \\
9 & HSBC Amanah Malaysia Berhad \\
10 & Hong Leong Islamic Bank Berhad \\
11 & Kuwait Finance House (Malaysia) Berhad \\
12 & Maybank Islamic Berhad \\
13 & OCBC Al-Amin Bank Berhad \\
14 & Public Islamic Bank Berhad \\
15 & RHB Islamic Bank Berhad \\
16 & Standard Chartered Saadiq Berhad \\
\hline
\end{tabular}

\section{Total 29}

Sumber: Data diolah, 2019

Teknik pengambilan sampel yang digunakan adalah salah satu teknik dari nonprobability sampling yaitu purposive sampling, dengan kriteria, (1) Bank syariah yang beroperasi selama periode 2013-2017; (2) Bank syariah yang menerbitkan annual report selama periode 2013 - 2017; dan (3) Bank yang tidak memiliki kepemilikan manajerial $\geq 5 \%$. Berdasarkan kriteria pemilihan sampel tersebut, diperoleh bank syariah yang akan digunakan sebagai sampel penelitian berjumlah 22 bank syariah dari 29 bank syariah di negara Indonesia dan Malaysia.

Metode yang digunakan dalam penelitian ini adalah deksriptif dan verifikatif. Sumber data dalam penelitian ini yaitu data sekunder, dengan teknik pengumpulan studi kepustakaan dan laporan data publikasi. Pengujian data menggunakan statistik deskriptif, uji beda t-test, uji asumsi klasik, analisis regresi data panel, uji f, dan uji t.

Indeks pengungkapan ICG atau Islamic Corporate Governance Disclosure Index (ICGDI) dalam penelitian ini menggunakan indeks pengungkapan ICG pada penelitian Yadiat dkk. (2017) yang dikembangkan dari standar CG LKS Internasional yang dikeluarkan oleh IFSB. IFSB telah menggeluarkan 2 standar khusus CG untuk bank syariah yaitu IFSB No. 3 tentang Guiding Principles on CG for Institutions Offering Only Islamic Financial Services (Excluding Islamic Insurance (Takaful) Institution and Islamic Mutual Funds) dan IFSB No. 10 tentang Guiding Principles Institutions on Shariah Governance Systems for Intitutions Offering Islamic Financial Services. Dan juga mengacu pada penelitian terdahulu yang relevan seperti Majid, Sulaiman dan Ariffin (2011), Darmadi (2013), Abdullah (2013), serta Grassa dan Matoussi (2014). Dengan total ICGDI terdiri dari 8 dimensi yang mencakup 64 item pengungkapan.

Tabel 2 Indeks Pengungkapan ICG

\begin{tabular}{clc}
\hline No & \multicolumn{1}{c}{ Dimensi Pengungkapan } & Jumlah Item \\
\hline A & $\begin{array}{l}\text { Sharia Governance } \\
\text { Dewan Pengawas Syariah (Shariah }\end{array}$ & 9 \\
1 & $\begin{array}{l}\text { Supervisory Board) } \\
\text { Unit Kepatuhan Syariah Internal (Internal }\end{array}$ & 4 \\
2 & $\begin{array}{l}\text { Shariah Compliance Unit) } \\
\text { Unit Audit Syariah Internal (Internal Sharia } \\
\text { Review/Audit Unit) }\end{array}$ & 4
\end{tabular}




\begin{tabular}{clc} 
B & General Governance & \\
4 & Dewan Direktur (Board of Director) & 7 \\
5 & Dewan Komite (Board Committees) & 10 \\
6 & Internal Kontrol dan Internal Audit (Internal & 7 \\
7 & Control and External Audit) & 14 \\
8 & Manajemen Risiko (Risk Management) & 9 \\
\hline & Investment Account Holder (IAH) & $\mathbf{6 4}$ \\
\hline Sumber: (Yadiat et al. 2017)
\end{tabular}

Berikut tabel operasionalisasi variabel yang menggambarkan setiap indikator variabel dalam penelitian ini:

Tabel 3 Tabel Operasionalisasi Variabel

\begin{tabular}{|c|c|c|c|c|}
\hline Variabel & $\begin{array}{c}\text { Sub } \\
\text { Variabel }\end{array}$ & $\begin{array}{c}\text { Konsep } \\
\text { Variabel }\end{array}$ & Indikator & Skala \\
\hline $\begin{array}{l}\text { Deposit } \\
\text { Structure }\end{array}$ & PSIA $\left(X_{1}\right)$ & $\begin{array}{l}\text { 1. (Antonio } \\
\text { 2001) } \\
\text { 2. (Grassa } \\
\text { 2018) }\end{array}$ & 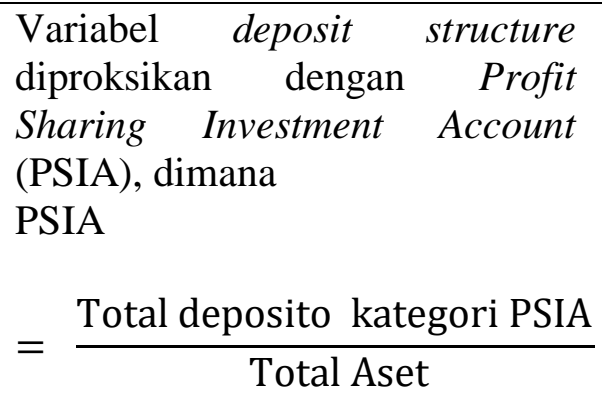 & Rasio \\
\hline $\begin{array}{l}\text { Ownership } \\
\text { Strcuture }\end{array}$ & $\begin{array}{c}\text { Kepemilikan } \\
\text { Manajerial } \\
\left(\mathrm{X}_{3}\right)\end{array}$ & $\begin{array}{l}\text { 1. (Grifiin } \\
\text { dan } \\
\text { Ebert } \\
\text { 2007,11 } \\
\text { 5) } \\
\text { 2. (Corner } \\
\text { et al. } \\
\text { Dalam } \\
\text { Herawati } \\
\text { 2014) } \\
\text { (Boediono } \\
\text { 2005) }\end{array}$ & $\begin{array}{l}\text { Kepemilikan Manajerial } \\
=\frac{\text { Jml saham dimiliki manajeme }}{\text { Jml modal saham yang bered }}\end{array}$ & Rasio \\
\hline $\begin{array}{c}\text { Pengungkap } \\
\text { an ICG (Y) }\end{array}$ & ICGD (Y) & $\begin{array}{l}\text { (Yadiat et } \\
\text { al. 2017) }\end{array}$ & $I C G D=\frac{\begin{array}{c}\text { Skor item yang } \\
\text { diungkapkan }\end{array}}{\begin{array}{c}\text { Skor maksimal } \\
\text { pengungkapan }\end{array}}$ & Rasio \\
\hline $\begin{array}{l}\text { Variabel } \\
\text { Kontrol }\end{array}$ & Profitability & $\begin{array}{l}\text { (Palepu et } \\
\text { al. 2014, } \\
211)\end{array}$ & $R O E=\frac{\text { net income }}{\text { equity }}$ & Rasio \\
\hline
\end{tabular}




$\begin{array}{clcc}\text { Leverage } & \begin{array}{l}\text { (Palepu et } \\ \text { al. 2014) }\end{array} & \text { Rasio } \\ \text { Size } & \begin{array}{l}\text { (Asnawi } \\ \text { dan Wijaya }\end{array} & \text { Size }=\log (\text { aset }) & \text { Rasio } \\ \text { Age } & \begin{array}{l}\text { 2005) } \\ \text { (Lestari P. }\end{array} & \text { Age }=\begin{array}{c}\text { lamanya bank syariah } \\ \text { berdiri }\end{array} & \text { Rasio } \\ & \text { 2013) } & \end{array}$

Sumber: Data diolah, 2019

\section{HASIL DAN PEMBAHASAN PENELITIAN}

\section{Statistik Deskriptif}

Statistik deskriptif digunakan untuk menganalisis data dengan cara mendeskripsikan dan menggambarkan data yang terkumpul untuk membuat kesimpulan umum terhadap populasi. Dalam penelitian ini analisis statistik deskriptif yang digunakan meliputi nilai minimum, maksimum, rata-rata dan simpangan baku.

Tabel 4 Analisis Deskriptif Variabel Penelitian

\begin{tabular}{ccccc}
\hline Ukuran & ICGD (\%) & PSIA & BLOCK (\%) & KEPMAN (\%) \\
\hline Mean & 63.02 & 0.33 & 98.31 & 0.0002 \\
Median & 63.28 & 0.16 & 100 & 0.0000 \\
Max & 75 & 0.78 & 100 & 0.0056 \\
Min & 51.56 & 0.00 & 79.80 & 0.0000 \\
Std. Dev & 6.35 & 0.31 & 5.63 & 0.0010 \\
\hline
\end{tabular}

Sumber: Data diolah, 2019

Interpretasi untuk hasil statistik deskriptif di atas adalah sebagai berikut: (1) Islamic Corporate Governance Disclosure Index. Dari hasi penelitian diperoleh rata-rata Islamic Corporate Governance Disclosure Index sebesar $63.02 \%$, dengan ICGD tertinggi sebesar 75\% dan ICGD terendah sebesar 51.56\%. Nilai rata-rata tersebut menunjukkan nilai yang lebih tinggi dibandingkan dengan rata-rata pengungkapan pada penelitian sebelumnya, hal ini menunjukkan bahwa terjadi peningkatan pengungkapan ICG pada bank syariah di Indonesia dan Malaysia secara umum.

(2) Profit Sharing Investment (PSIA) adalah rasio total deposit yang termasuk kategori PSIA terhadap total aset. Hasil penelitian diperoleh rata-rata PSIA sebesar 0,33, dengan PSIA tertinggi sebesar 0,78 dan PSIA terendah sebesar 0,00. Nilai rata-rata PSIA dari sampel yang diteliti tergolong rendah apabila dibandingkan dengan persentase rata-rata jumlah PSIA pada bank syariah di negara Timur Tengah dan Asia Tenggara, yaitu $62 \%$.

(3) Blockholders Ownership $=$ rasio total saham yang dimiliki blockholders terhadap jumlah saham yang beredar. Hasil penelitian diperoleh ratarata Blockholders Ownership sebesar 98,31\%, dengan Blockholders Ownership tertinggi sebesar 100,0 \% dan Blockholders Ownership terendah sebesar 79,80\%. 
Blockholder Ownership menunjukkan konsentrasi kepemilikan pada bank syariah di Indonesia dan Malaysia yang tinggi.

(4) Kepemilikan Manajerial = persentase jumlah saham yang dimiliki manajerial dari seluruh jumlah saham yang beredar (Gideon Boediono, 2005). Hasil penelitian diperoleh rata-rata Kepemilikan Manajerial sebesar 0,0002\%, dengan Kepemilikan Manajerial tertinggi sebesar $0.0056 \%$ dan Kepemilikan Manajerial terendah sebesar $0,00 \%$. Kepemilikan manajerial pada bank syariah di Indonesia dan Malaysia terbilang rendah.

Tabel 5 Analisis Deskriptif Variabel Dependen per Negara

\begin{tabular}{ccc}
\hline Dimensi & Indonesia & Malaysia \\
\hline Sharia Governance & $55,6 \%$ & $66,7 \%$ \\
General Governance & $78,6 \%$ & $70,3 \%$ \\
\hline ICGD & $\mathbf{6 7 , 2 \%}$ & $\mathbf{5 9 , 6 \%}$ \\
\hline Sumber: Data
\end{tabular}

Sumber: Data diolah, 2019

Pengungkapan ICG pada penelitian ini terdiri dari Sharia Governance (SG) dan General Governance (GG). Pada Tabel 5 dapat dilihat bahwa secara keseluruhan pengungkapan ICG pada bank syariah di Indonesia lebih tinggi daripada pengungkapan ICG di Malaysia. GG pada kedua negara memiliki skor pengungkapan yang lebih tinggi dibandingkan dengan pengungkapan SG. Namun, pada SG, bank syariah Malaysia memiliki skor pengungkapan yang lebih tinggi. Regulasi terkait dengan Sharia Governance (SG) di Indonesia dan Malaysia apabila diperbandingkan menunjukkan regulasi $S G$ di Malaysia lebih komprehensif dibandingkan dengan regulasi SG di Indonesia, hal ini ditunjukkan berdasarkan implementasi standar AAOIFI dan IFSB yang diterapkan pada regulasi SG di Indonesia dan Malaysia (Amalia 2017).

Secara umum, dapat disimpulkan dengan rata-rata pengungkapan ICG 63\% pada bank syariah di Indonesia dan Malaysia menunjukkan tingkat pengungkapan yang cukup baik. Namun pengungkapan SG masih rendah dibandingkan dengan pengungkapan GG. Aspek syariah pada bank syariah harus ditingkatkan guna menambah nilai tambah bank syariah dibandingkan dengan bank konvensional, dan juga untuk menjaga nasabah bank syariah yang memilih bank syariah berdasarkan motif religius yang tentunya memperhatikan kepatuhan syariah. Penelitian Echchabi (2012) menunjukkan nasabah bank syariah di Malaysia utamanya dipacu oleh motif religius dari para nasabah tersebut. Sedangkan, nasabah bank syariah di Indonesia lebih didominasi oleh nasabah rasional yang mengedepankan aspek rasional dalam pengambilan keputusan untuk menabung di bank syariah.

\section{Analisis Regresi Data Panel}

Sebelum dilakukan pembentukan model regresi, selanjutnya dilakukan pengujian asumsi terlebih dahulu supaya model yang terbentuk memberikan estimasi yang BLUE (Best Linier Unbiased Estimated). Pengujian asumsi ini terdiri atas empat pengujian, yakni uji normalitas, uji multikolinieritas, uji heteroskedastistias dan uji autokorelasi. 
Dependent Variable: ICGD

Tabel 4 Persamaan Regresi Data Panel

Method: Panel Least Squares

Date: 10/15/19 Time: 15:56

Sample: 20132017

Periods included: 5

Cross-sections included: 12

Total panel (balanced) observations: 60

\begin{tabular}{crrrr}
\hline \hline Variable & Coefficient & Std. Error & t-Statistic & Prob. \\
\hline \hline C & -1.020728 & 0.635655 & -1.605790 & 0.1144 \\
PSIA & 0.061917 & 0.019127 & 3.237168 & 0.0021 \\
BLOCK & 0.925226 & 0.278036 & 3.327726 & 0.0016 \\
KEPMAN & -0.102038 & 2.258441 & -0.045181 & 0.9641 \\
PROF & 0.002781 & 0.000872 & 3.189608 & 0.0024 \\
LEV & -0.082029 & 0.014611 & -5.614022 & 0.0000 \\
SIZE & 0.809598 & 0.229029 & 3.534916 & 0.0009 \\
AGE & 0.265858 & 0.054987 & 4.834919 & 0.0000 \\
\hline \hline R-squared & 0.753675 & Mean dependent var & 1.797500 \\
Adjusted R-squared & 0.720516 & S.D. dependent var & 0.046746 \\
S.E. of regression & 0.024713 & Akaike info criterion & -4.439428 \\
Sum squared resid & 0.031757 & Schwarz criterion & -4.160182 \\
Log likelihood & 141.1828 & Hannan-Quinn criter. & -4.330199 \\
F-statistic & 22.72901 & Durbin-Watson stat & 0.591182 \\
Prob(F-statistic) & 0.000000 & & \\
\hline \hline
\end{tabular}

Sumber: Output Data, 2019

Persamaan regresi yang akan dibentuk adalah sebagai berikut: ICGD= $1,021+0,062$ PSIA + 0,925 BlOCK - 0,102 KEPMAN, Nilai konstanta -1,021 menunjukkan besarnya rata-rata Islamic Corporate Governance jika PSIA dan variabel lainnya bernilai 0 (nol). Koefisien regresi untuk PSIA $\left(\mathrm{X}_{1}\right)$ adalah sebesar 0,062 dan bertanda positif, artinya setiap terjadi peningkatan PSIA dan variabel bebas lainnya diasumsikan konstan, maka diprediksikan akan meningkatkan nilai PSIA sebesar 0,062. Nilai PSIA yang tinggi menunjukkan bahwa Islamic Corporate Governance tinggi/meningkat. Koefisien regresi untuk BLOCK $\left(\mathrm{X}_{2}\right)$ adalah sebesar 0,925 dan bertanda positif, artinya setiap terjadi peningkatan blockholder ownership dan variabel bebas lainnya diasumsikan konstan, maka diprediksi akan meningkatkan Islamic Corporate Governance sebesar 0,925. Koefisien regresi untuk KEPMAN $\left(\mathrm{X}_{3}\right)$ adalah sebesar -0,102 dan bertanda negatif, artinya setiap terjadi peningkatan kepemilikan manajerial dan variabel bebas lainnya diasumsikan konstan, maka diprediksi akan menurunkan Islamic Corporate Governance sebesar 0,102.

Koefisien determinasi digunakan untuk melihat besarnya kontribusi yang diberikan oleh Profit Sharing Investment Account, Blockholder Ownership, dan Kepemilikan Manajerial terhadap Pengungkapan Islamic Corporate Governance. Pada tabel 4.7 di atas, diketahui nilai R-Squared yang diperoleh sebesar 0,754 atau 75,4\%. Hasil tersebut menunjukkan bahwa Profit Sharing Investment Account, Blockholder Ownership, dan Kepemilikan Manajerial secara simultan 
memberikan kontribusi sebesar 75,4\% terhadap Pengungkapan Islamic Corporate Governance, sedangkan $24,6 \%$ sisanya merupakan pengaruh dari faktor lain yang tidak diteliti.

Tabel 5 Uji F (Simultan)

\begin{tabular}{cccccl}
\hline $\mathbf{F}_{\text {hitung }}$ & $\mathbf{F}_{\text {tabel }}$ & Prob. & $\boldsymbol{\alpha}$ & Keputusan & Kesimpulan \\
\hline 22,729 & 2,192 & 0,002 & 0,05 & $\mathrm{H}_{0}$ ditolak & signifikan \\
\hline Sumber: Data diolah, 2019 & & & &
\end{tabular}

Berdasarkan hasil pengujian, diketahui bahwa nilai $F_{\text {hitung }}$ sebesar 22,729 jauh lebih besar dari pada nilai $F_{\text {tabel }}$ 2,192, dan nilai probabilitas sebesar 0,002 menunjukkan secara simultan Profit Sharing Investment Account, Blockholder Ownership, dan Kepemilikan Manajerial berpengaruh signifikan terhadap pengungkapan Islamic Corporate Governance.

\section{Pengaruh Deposit Structure Terhadap Pengungkapan Islamic Corporate Governance pada Perbankan Syariah di Indonesia dan Malaysia}

Berdasarkan hasil uji t parsial, diperoleh bahwa variabel deposit structure memiliki koefisien regresi sebesar 0,0021 lebih kecil dari nilai signifikansi 0,05. Hal ini menunjukkan bahwa variabel deposit structure secara individu berpengaruh positif dan signifikan terhadap pengungkapan Islamic Corporate Governance. Oleh karena itu, hipotesis yang menyatakan bahwa variabel deposit structure berpengaruh positif terhadap pengungkapan Islamic Corporate Governance diterima.

Hal ini menunjukkan bahwa bank syariah dengan komposisi kepemilikan PSIA yang tinggi, memiliki tingkat pengungkapan Islamic Corporate Governance yang lebih tinggi. Perbankan syariah perlu meningkatkan pengungkapannya untuk menjaga dari risiko yang besar atas penarikan dana oleh para pemilik PSIA.

Sebagai pengembangan penelitian Grassa (2018), hasil penelitian ini mendukung hasil penelitian Grassa (2018) yang menunjukkan bahwa bank syariah melakukan pengungkapan Islamic Corporate Governance yang lebih tinggi pada bank syariah dengan komposisi Profit Sharing Investment Account (PSIA) yang lebih besar. Bagaimanapun, Malghaes dan Al-Saad, 2013 dalam Grassa (2018) menyatakan, dalam praktiknya, dalam menjaga hak para pemilik PSIA, tidak cukup efektif dari sisi CG saja.

\section{Pengaruh Blockhoder Ownership Terhadap Pengungkapan Islamic Corporate Governance pada Perbankan Syariah di Indonesia dan Malaysia}

Berdasarkan hasil uji parsial diperoleh bahwa variabel Kepemilikan Blockholder memiliki koefisien regresi sebesar 3,327 lebih besar dari nilai t tabel $-1,675$ ( $\left.t_{\text {hitung }}>-t_{\text {tabel }}\right)$. Hal ini menunjukkan bahwa variabel Kepemilikan Blockholder secara individu tidak berpengaruh negatif dan signifikan dalam mempengaruhi pengungkapan ICG pada perbankan syariah di Indonesia dan Malaysia. Oleh karena itu, hipotesis yang menyatakan bahwa variabel Kepemilikan Blockholder berpengaruh negatif terhadap pengungkapan ICG ditolak.

Berdasarkan nilai koefisien regresi, kepemilikan blockholder memiliki nilai koefisien regresi sebesar 0,0016, lebih kecil dari nilai signifikansi 0,05. Hasil 
pengujian tersebut menunjukkan pengaruh signifikansi positif, yang artinya Kepemilikan Blockholder berpengaruh positif signifikan terhadap tingkat pengungkapan Islamic Corporate Governance.

Hasil penelitian ini tidak sama dengan hasil penelitian sebelumnya yang dilakukan oleh Grassa (2018) yang menunjukkan Kepemilikan Blockholder berpengaruh negatif terhadap pengungkapan Islamic Corporate Governance. Begitupun hasil penelitian Khan dkk (2017) yang menunjukkan Kepemilikan Blockholder berpengaruh negatif terhadap implementasi dan pengungkapan Islamic Corporate Governance.

Kepemilikan blockholder yang besar menunjukkan kepemilikan yang terkonsentrasi. Pada penelitian Sijabat (2017), konsentrasi kepemilikan berpengaruh positif terhadap risiko bank, yang artinya semakin terkonsentrasi kepemilikan maka semakin besar risiko bank tersebut.

Peningkatan kepemilikan saham, akan berbanding lurus dengan cash flow terhadap pemegang saham. Jika harga saham atau nilai perusahaan turun maka pemegang saham pengendali yang paling banyak merasakan dampak kerugian dari penurunan nilai perusahaan tersebut. Capital markets transactions hypothesis Healy dan Palepu (2001) menghipotesiskan bahwa ketika manajemen/pemegang saham pengendali perusahaan berada pada posisi superior information, maka akan menimbulkan asimetri informasi antara pemegang saham pengendali/ manajemen dengan pemegang saham minoritas. Tingginya asimetri informasi akan meningkatkan biaya modal sehingga akan menurunkan harga saham perusahaan tersebut, oleh karena itu pemegang saham pengendali harus menjaga kepentingan pemengang saham minoritas dengan mendorong manajemen untuk meningkatkan pengungkapan informasi guna mengurangi asimetri informasi.

\section{Pengaruh Managerial Ownership Terhadap Pengungkapan Islamic Corporate Governance pada Perbankan Syariah di Indonesia dan Malaysia}

Berdasarkan hasil uji parsial diperoleh bahwa variabel Kepemilikan Manajerial memiliki koefisien regresi sebesar -0,045 lebih besar dari -1,675 ($\left.\mathrm{t}_{\text {tabel}}\right)$. Hal ini menunjukkan bahwa variabel Kepemilikan Manajerial secara individu tidak berpengaruh negatif dan signifikan dalam mempengaruhi pengungkapan Islamic Corporate Governance pada perbankan syariah di Indonesia dan Malaysia. Oleh karena itu, hipotesis yang menyatakan bahwa variabel managerial ownership berpengaruh negatif terhadap pengungkapan Islamic Corporate Governance ditolak.

Hasil penelitian ini tidak sejalan dengan penelitian Elmagrhi dkk (2016) yang menunjukkan bahwa kepemilikan manajerial berpengaruh negatif terhadap pengungkapan sukarela Corporate Governance. Penelitian ini mendukung penelitian sebelumnya yang dilakukan oleh Juhmani (2013) dan Nelwan (2017) yang membuktikan bahwa kepemilikan saham oleh pihak manajemen tidak berpengaruh terhadap pengungkapan. Hal ini dimungkinkan karena statistik jumlah kepemilikan manajerial rata-rata pada sampel penelitian relatif kecil, sehingga besarnya kepemilikan manajerial tidak mempengaruhi pengungkapan Islamic Corporate Governance. 


\section{KESIMPULAN}

Berdasarkan hasil penelitian dan pembahasan yang telah diuraikan pada bab sebelumnya, maka peneliti mengambil beberapa kesimpulan yaitu: PSIA berpengaruh positif signifikan terhadap pengungkapan Islamic Corporate Governance pada perbankan syariah pada negara Indonesia dan Malaysia periode 2013-2017. Tingkat pengungkapan ICG lebih tinggi pada bank syariah yang memiliki komposisi PSIA yang tinggi, hal ini dilakukan bank syariah dalam rangka mengantisipasi risiko penarikan dana oleh para pemilik PSIA. Ownership Structure dalam penelitian ini yaitu; (a) Blockholder Ownership berpengaruh positif signifikan terhadap pengungkapan Islamic Corporate Governance pada perbankan syariah pada negara Indonesia dan Malaysia (BEI) tahun 2013-2017. Bank syariah dengan konsentrasi kepemilikan yang tinggi melakukan pengungkapan ICG yang lebih banyak daripada bank syariah dengan kepemilikan blockholder yang rendah, (b) Kepemilikan manajerial tidak berpengaruh negatif signifikan terhadap pengungkapan Islamic Corporate Governance pada perbankan syariah pada negara Indonesia dan Malaysia (BEI) tahun 2013-2017. Hal ini dimungkinkan karena jumlah kepemilikan manajerial yang sangat sedikit, sehingga besarnya kepemilikan manajerial tidak berpengaruh terhadap pengungkapan ICG. Secara simultan, PSIA dan Blockholder Ownership, Kepemilikan Manajerial berpengaruh signifikan terhadap pengungkapan Islamic Corporate Governance pada perbankan syariah pada negara Indonesia dan Malaysia (BEI) tahun 2013-2017 dengan kontribusi pengaruh yang diberikan sebesar $75,4 \%$.

\section{DAFTAR PUSTAKA}

Abdullah, Wan Amalina; Majella Percy \& Jenny Stewart. 2013. Sharia disclosure in Malaysian and Indonesian Islamic banks: The sharia governance system. Journal of Islamic Accounting and Business Research 4 (2), 100131.

Abu-Tapanjeh, Abdussalam Mahmoud. 2009. Corporate governance from the Islamic perspective: A comparative analysis with OECD principles. Critical Perspectives on Accounting 20, 556-567.

Albassam, Waleed M., \& Collins G. Ntim. 2017. The effect of Islamic values on voluntary corporate governance disclosure: The case of Saudi-listed firms. Journal of Islamic Accounting and Business Research 8 (2), 182202.

Antonio, Muhammad Syafi'i. 2001. Bank Syariah: Dari teori ke praktik. Jakarta: Gema Insani.

Archer, S.; Karim, A.A.R. and Sundararajan, V. 2010. "Supervisory, regulatory, and capital adequacy implications of profit-sharing investment accounts in Islamic finance". Journal of Islamic Accounting and Business Research 1 (1), 10-31.

Asnawi, Said Kelana dan Chandra Wijaya. 2005. Riset Keuangan: Pengujianpengujian Empiris. Jakarta: PT Gramedia. 
Bhatti, Maria \& Ishaq Bhatti. 2009. Development in legal issues of corporate governance in Islamic finance. Journal of Economic and Administrative Sciences 25 (1), 67-91.

Boediono, Gideon Setyo Budiwitjaksono. 2005. Kualitas laba: Studi pengaruh mekanisme corporate governance dan dampak manajemen laba dengan menggunakan analisis jalur. Simposium Nasional Akuntansi VIII, 172.

Chong, Beng and Ming-Hua Liu. 2009. "Islamic banking: Interest-free or interestbased?". Pacific-Basin Finance Journal 17 (1), 125-144.

Darmadi, Salim. 2013. Corporate governance disclosure in the annual report: An exploratory study on Indonesian Islamic banks. Humanomics 29 (1), 4-23.

Elmagrhi, Mohamed H.; Collins G. Ntim \& Yan Wang. 2016. Antecedents of voluntary corporate governance disclosure: A post-2007/08 financial crisis evidence from the influential UK Combined Code. Corporate Governance 16 (3), 507-538.

Grassa, R. 2018. Deposits structure, ownership concentration and corporate governance disclosure in GCC Islamic banks: Empirical evidence. Journal of Islamic Accounting and Business Research 9 (4), 587-606.

Hasan, Zulkifli. 2009. Corporate Governance: Western and Islamic Perspectives. International Reviewof Business Research Papers 5 (1), 277-293.

Herawati, N.T.; Sulindawati; Ni Luh G.E.; Kristiani, K.E. 2014. Pengaruh Mekanisme Corporate Governance dan Ukuran Perusahaan terhadap Manajemen Laba pada Perusahaan Manufaktur yang Terdaftar di BEI. $e$ Journal S1 Ak Universitas Pendidikan Ganesha 2 (1).

Healy, Paul M. and Krisnan G. Palepu. 2001. Information Asymmetry, Corporate Disclosure, and Capital Market. A Review of Empirical Disclosure Literature. Journal of Accounting and Economic 31 (2001), 405-440.

Herwiyanti, E.; Ma, R. A. S. W., \& Rosada, A. A. 2015. Analysis of factors influencing the islamic corporate governance disclosure index of Islamic Banks in Asia. Int. J. Humanit. Manag. Sci. 3, 2320-4044.

Hikmah, N., \& Rahmayanti, D. 2011. Faktor-Faktor yang Mempengaruhi Luas Pengungkapan Corporate Governance dalam Laporan Tahunan Perusahaan Perbankan yang Terdaftar Di BEI. Simposium Nasional Akuntansi XIV, 132.

IFSB. 2009, Guiding Principles on Shariah Governance Systems for Institutions Offering Islamic Financial Sevices, December 2009.

Jao, R. dan Pagalung, G. 2011. Corporate Governance, Ukuran Perusahaan, dan Leverage terhadap Manajemen Laba Perusahaan Manufaktur Indonesia, Jurnal Akuntansi \& Auditing 8 (1), 43-54.

Juhmani, Omar. 2013. Ownership Structure and Corporate Voluntary Disclosure: Evidence from Bahrain. International Journal of Accounting and Financial Reporting 20133 (2).

Khan, M. Y.; Awan, T.; Saleem, N. \& Javeed, A. 2017. The Impact of Islamic Governance Mechanisms on Corporate Governance Compliance and Disclosure. Empiring Issues in Economics and Finance (AIC-EIEF 2017).

Lestari, Puji. 2013. Determinants of islamic social reporting in syariah banks: Case of Indonesia. International Journal of Business and Management Invention 2 (10), 28-34. 
Lewis, M. K. 2005. Islamic Corporate Governance. Review of Islamic Economics 9 (1), 5-29.

Nelwan, M. L. 2017. Corporate Governance Disclosure in the Existence of Ownership Structure and Growth Opportunities. Jurnal Keuangan dan Perbankan 21 (2).

Ntim, Collins G.; Opong, K.; Danbolt, J. and Thomas, D. 2012. "Voluntary corporate governance disclosures by post-Apartheid South African corporations', Journal of Applied Accounting Research, 13(2): 122-144.

Nuryaman, N. 2009. Pengaruh Konsentrasi Kepemilikan, Ukuran Perusahaan, Dan Mekanisme Corporate Governance Terhadap Pengungkapan Sukarela. Jurnal Akuntansi dan Keuangan Indonesia 6 (1), 89-116.

Palepu, Krishna G.; Healy, Paul M. and Bernard, Victor L. 2014. Business analysis and valuation: using financial statement, 3e. Thomson South Western.

Safieddine, A. 2009. "Islamic financial institutions and corporate governance: new insights for agency theory", Corporate Governance: An International Review 17 (2), 142-58.

Scott, William R. 2011. Financial Accounting Theory. Fifth Edition. USA: Prentice-Hall.

Sijabat, Yacobo P. 2017. Pengaruh Konsentrasi Kepemilikan dan Tipe Kepemilikan terhadap Kinerja dan Risiko Perbankan di Indonesia. Tesis Magister Universitas Gadjah Mada.

Srairi, Samir. 2015. Corporate Governance Disclosure Practices and Performance of Islamic Banks in GCC Countries. Journal of Islamic Finance 176 (3132), 1-17.

Sulaiman, Maliah; Norakma Abd Majid \& Noraini Mohd Ariffin. 2015. Corporate governance of Islamic financial institutions in Malaysia. Asian Journal of Business and Accounting 8 (1), 65-94.

Thomsen, S.; Pedersen, T. \& Kvist, H.K. 2006. Blockholder ownership: Effects on firm value in market and control based governance systems, Journal of Corporatwie Finance: 246-269.

Yadiat, Winwin; Gustani \& Amrania, Gia. 2017. Pengaruh Pengungkapan Islamic Corporate Governance dan Islamic Corporate Social Responsibility terhadap Disiplin Pasar dengan Kinerja Keuangan sebagai Variabel Intervening (Studi Empiris pada Bank Syariah di Negara QISMUT. International Journal of Applied Business and Economic Research 15 (24). 